\title{
Technical Possibilities for Implementing Measures to Reduce the Emitted Electromagnetic Field of a High-voltage Distribution Transformer
}

\author{
Miroslava Jámborová ${ }^{1}$, Tibor Dzuro ${ }^{1 *}$, Ervin Lumnitzer ${ }^{1}$, Pavol Liptai ${ }^{2}$ \\ Technical University of Kosice, Faculty of Mechanical Engineering, Department of Process and Environmental Engineering, Park Komenskeho 5 , \\ 042 00, Kosice, Slovakia \\ Technical University of Kosice, Faculty of Materials, Metallurgy and Recycling, Letna 9, 042 00, Kosice, Slovakia
}

\begin{abstract}
This paper deals with the measurement of electromagnetic field parameters near high voltage systems, characteristics of electric field, magnetic field and electromagnetic field, as well as the possibilities of implementing measures to reduce the emitted electromagnetic field. The paper describes the measurement of electromagnetic field parameters in the vicinity of high voltage systems, the analysis and synthesis of the measurement results in the external and internal environment of particular transformer stations is evaluated. The objects of interest in these measurements were brick transformer stations for transforming AC voltage from $22 \mathrm{kV}$ to $400 \mathrm{~V}$ and $230 \mathrm{~V}$ at the operating frequency of $50 \mathrm{~Hz}$. With regard to the influence of electromagnetic fields in the environment, individual measurements were assessed in accordance with selected criteria.
\end{abstract}

Keywords: electromagnetic field, transformers, electric energy, magnetic field

\section{Introduction}

The electromagnetic field is one of the forms of manifestation of matter and represents one another influencing electric field variables and magnetic field. Through it him the action is carried out between the electrically charged particles. The relation between electrical the magnetic field is that any change of one of the fields results in the formation of the other field. Electromagnetic field propagates in space by electromagnetic waves. Electromagnetic field as radiation is characterized by wavelength, frequency and the intensity of the magnetic and electric fields. It has a wave corpuscular character, thus reports both as a wave and as a particle.

The relation between frequency and wavelength is expressed by the following formula [1].

$f=\frac{c}{\lambda}$

where : c - speed of light, $\lambda$ - wavelength.

The aim of the present article was to measure the values of electric field intensity and magnetic induction in ten transformer stations located near residential blocks in city district Kosice - Terasa. The paper deals with the measurement of electromagnetic field parameters in the vicinity of high-voltage systems, as well as with the characteristics of electric, magnetic and electro-magnetic fields. The aim of the post is measurement of parameters and analysis of results of individual measurements and evaluation of measurements, as well as recommended measures to improve the identified situation. 


\section{Experimental Section}

\section{Measurement of electromagnetic field parameters}

For measuring EMP as well as sound Class 1 measuring, instruments that meet the requirements of STN EN 50413: 2009 and requirements specified in Act No. 142/2000 Coll. on Metrology and on Amendments to Certain Acts, as amended [2,3] are used. The objects of interest in these measurements were brick transformer stations for transforming $A C$ voltage from $22 \mathrm{kV}$ to $400 \mathrm{~V}$ and $230 \mathrm{~V}$ at the operating frequency of $50 \mathrm{~Hz}$.

Ten transformer stations were evaluated and measured, all of which were located in residential areas of Kosice - Terasa. A view of one of these transformer stations (TS) is shown in Fig. 1. Photographic image of one bricked TS is shown in Fig. 2. The largest sources of electromagnetic fields at these stations are high voltage transformers. Furthermore, there are electrical elements of the substation such as cable distribution, protection and protection devices.

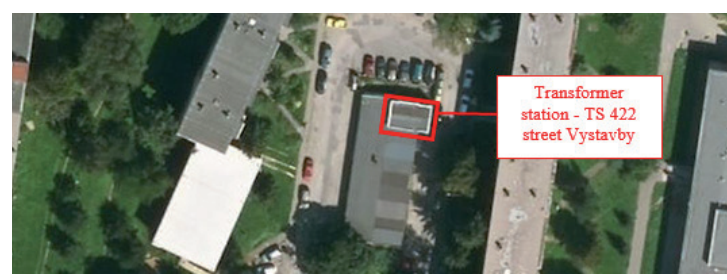

Figure 1: Satellite view of transformer station.

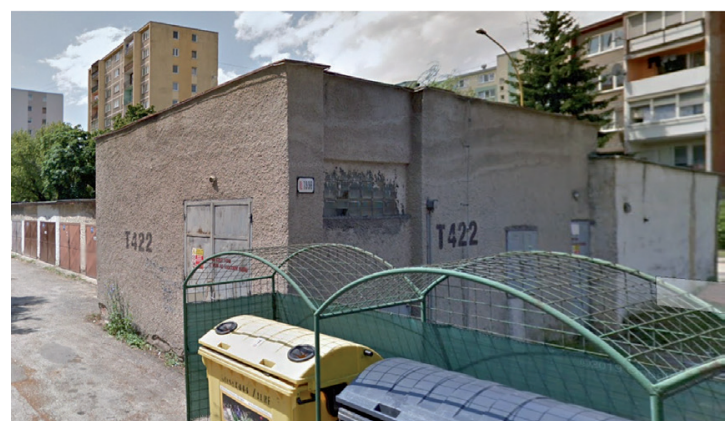

Figure 2: Brick transformer station on the street Vystavby - city district Kosice-zapad.

\section{Measuring instruments}

For measuring the electromagnetic field, a measuring chain consisting of [4] was used (Fig. 3).

- Narda EFA 300 electromagnetic field analyser, PN 2245/30, serial number $\mathrm{U}-0020$, frequency range from $5 \mathrm{~Hz}$ to $32 \mathrm{kHz}$,

- Probe for measuring the electric field component (electric field strength E), Narda BN 2245/90.31, serial number S-0018, measuring range from $1 \mathrm{~V} / \mathrm{m}$ to $100 \mathrm{kV} / \mathrm{m}$,
- Probe for measuring the magnetic field component (magnetic induction B), Narda BN 2245 / 90.10, serial number A0-0005, measuring range from $100 \mathrm{nT}$ to $32 \mathrm{mT}$.

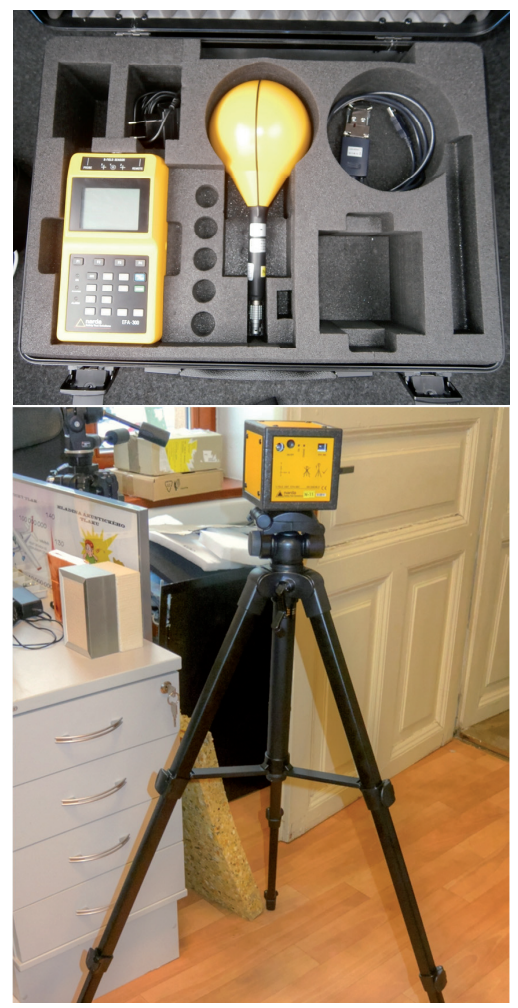

Figure 3: Measuring chain of electromagnetic fields.

For this measurement chain, internal guideline no. IS - ÚOFP / EP / 01/12 (working procedure for measurement, objectification and evaluation of electromagnetic field variables in working and the environment and to determine uncertainty in the measurement process) was followed. The expanded measurement string uncertainty for both the E-probe and the B-probe was determined to be $29.1 \%$.

\section{Measurement procedure}

In all measurement cases, the minimum distance between the probe tip and the body of the measuring technician, as well as any reflecting object, is $1 \mathrm{~m}$ when measuring below $300 \mathrm{MHz}$. The distance of the person carrying out the measurement from the measuring probe must be large, so that the effect of their proximity is less than $3 \%$. The electric field strength of nonhomogeneous fields (e.g. around devices and earthed structures in substations) shall be measured 
at a horizontal distance of more than $0,5 \mathrm{~m}$ from grounded constructions $[5,6]$. The measurements were performed in the frequency range from $30 \mathrm{~Hz}$ to $2 \mathrm{kHz}$. During the measurement, the RMS mode was set for effective values. All measurements inside the object were made at a distance of $2 \mathrm{~m}$ from the high-voltage transformer at a height of $1.5 \mathrm{~m}$, which approximately corresponds to the height of the geometric centre of the head and torso of an average adult standing person. Measuring points in the outdoor environment were carried out at a distance of $1 \mathrm{~m}$ from the transformer metal door in the direction of the 1,5 $\mathrm{m}$ residential blocks above ground level. An illustration of one external measuring point is shown in Fig. 4.

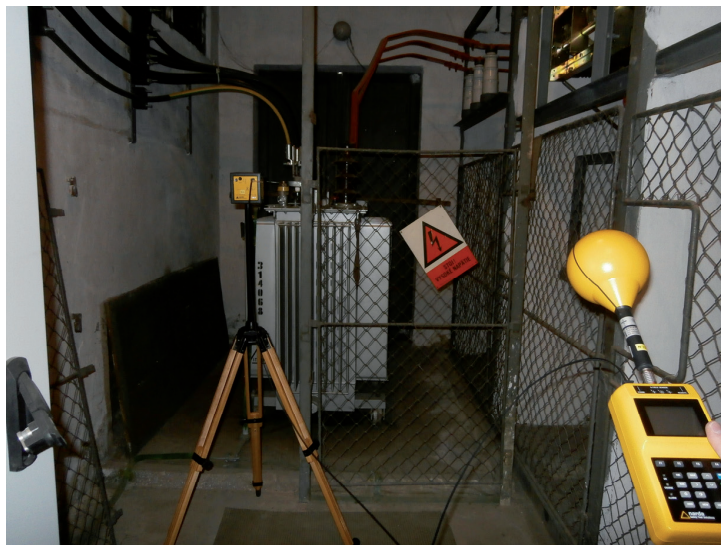

Figure 4: Measuring point at the object.

\section{Results and Discussion}

The measurement results are presented in tabular form. The results of the measurement of the electric field intensity $\mathrm{E}$ and the magnetic induction $\mathrm{B}$ inside the ten transformer station objects are shown in Tab. 1. During the measurements inside the TS objects, atmospheric conditions were also recorded and were in the range of:

- air temperature $-t=4 \div 5^{\circ} \mathrm{C}$,

- atmospheric pressure $-p=996 \div 1002 \mathrm{hPa}$,

- relative humidity $-70 \div 78 \%$.

The results of measurement of the electric field intensity $E$ and the magnetic induction $B$ in the external environment are shown in Tab. 2. Atmospheric conditions, were in the range of:

- air temperature $-t=10 \div 12^{\circ} \mathrm{C}$,

- atmospheric pressure $-p=998 \div 1006 \mathrm{hPa}$,

- relative humidity $-58 \div 65 \%$.
Table 1: Results of electric field intensity and magnetic induction measurement inside TS objects.

\begin{tabular}{|l|l|l|l|}
\hline No. & $\begin{array}{l}\text { Place of measurement } \\
\text { (Internal environment) }\end{array}$ & $\begin{array}{l}\text { Measured value } \\
\text { of electric field } \\
\text { intensity } \\
(\mathrm{E})[\mathrm{V} / \mathrm{m}]\end{array}$ & $\begin{array}{l}\text { Measured } \\
\text { value of magnetic } \\
\text { induction } \\
\text { (B) }[\mu \mathrm{T}]\end{array}$ \\
\hline 1 & TS 403 Obrody & 33,62 & 13,17 \\
\hline 2 & TS 409 Sokolovská & 35,41 & 15,10 \\
\hline 3 & TS 411 Pokroku & 34,35 & 8,05 \\
\hline 4 & TS 415 Obrody & 37,15 & 9,98 \\
\hline 5 & TS 419 Čapajevova & 31,36 & 11,49 \\
\hline 6 & TS 421 Kysucká & 39,80 & 6,21 \\
\hline 7 & TS 422 Vystavby & 39,83 & 16,70 \\
\hline 8 & TS 423 L’udová & 37,73 & 10,11 \\
\hline 9 & TS 424 Slobody & 33,32 & 10,01 \\
\hline 10 & TS 430 Hronská & 34,46 & 12,04 \\
\hline
\end{tabular}

Table 2: Results of electric field intensity and magnetic induction measurement in outdoor environment.

\begin{tabular}{|l|l|l|l|}
\hline No. & $\begin{array}{l}\text { Place of measurement } \\
\text { (External environment) }\end{array}$ & $\begin{array}{l}\text { Measured value } \\
\text { of electric field } \\
\text { intensity } \\
(\mathrm{E})[\mathrm{V} / \mathrm{m}]\end{array}$ & $\begin{array}{l}\text { Measured } \\
\text { value of magnetic } \\
\text { induction } \\
(\mathrm{B})[\mu \mathrm{\mu T}]\end{array}$ \\
\hline 1 & TS 403 Obrody & 0,788 & 695,7 \\
\hline 2 & TS 409 Sokolovská & 0,723 & 682,8 \\
\hline 3 & TS 411 Pokroku & 0,742 & 601,8 \\
\hline 4 & TS 415 Obrody & 0,878 & 732,6 \\
\hline 5 & TS 419 Čapajevova & 1,250 & 609,8 \\
\hline 6 & TS 421 Kysucká & 0,859 & 653,3 \\
\hline 7 & TS 422 Vystavby & 0,888 & 600,8 \\
\hline 8 & TS 423 L'udová & 0,941 & 700,2 \\
\hline 9 & TS 424 Slobody & 0,784 & 681,6 \\
\hline 10 & TS 430 Hronská & 0,849 & 699,1 \\
\hline
\end{tabular}

\section{Analysis of results and evaluation}

Measurement results of magnetic induction values Bef and Eef plus uncertainty and comparison with action values for impact on employee are given in Tab. 3. Measurement results of magnetic induction values $B_{\text {ef }}$ and $E_{\text {ef }}$ plus uncertainty and comparison with action values for impact on population are given in Tab. 4.

Based on the results of measurements of electric field intensity and magnetic induction evaluated for the frequency of $50 \mathrm{~Hz}$, at the places where the employees of the East Slovak power plants are moving and thus inside the transformer station objects, pursuant to the Regulation of the 
Table 3: Comparison of assessed values (EC) with legislation for impact on employees.

\begin{tabular}{|c|c|c|c|c|c|c|}
\hline Identification of & $\begin{array}{l}\text { Measured values of } \\
\text { electric field intensity }\end{array}$ & $\begin{array}{l}\text { Eef values plus } \\
\text { expanded uncertainty }\end{array}$ & $\begin{array}{l}\text { Measured values of } \\
\text { magnetic induction }\end{array}$ & $\begin{array}{l}\text { Bef values plus } \\
\text { expanded uncertainty }\end{array}$ & $\begin{array}{l}\text { Action value for } \\
\text { electric field strength }\end{array}$ & $\begin{array}{l}\text { Action value for } \\
\text { magnetic induction }\end{array}$ \\
\hline & $E_{\text {ef }}\left[V \cdot m^{-1}\right]$ & $E_{c}\left[V \cdot m^{-1}\right]$ & $\mathrm{B}_{\mathrm{ef}}[\mu \mathrm{T}]$ & $B_{c}[\mu T]$ & $E_{R}\left[V \cdot m^{-1}\right]$ & $B_{R}[\mu T]$ \\
\hline TS 403 Obrody & 33,62 & 43,40 & 13,17 & 17,00 & \multirow{10}{*}{10000} & \multirow{10}{*}{500} \\
\hline TS 409 Sokolovská & 35,41 & 45,71 & 15,10 & 19,49 & & \\
\hline TS 411 Pokroku & 34,35 & 44,34 & 8,05 & 10,39 & & \\
\hline TS 415 Obrody & 37,15 & 47,96 & 9,98 & 12,88 & & \\
\hline TS 419 Čapajevova & 31,36 & 40,48 & 11,49 & 14,83 & & \\
\hline TS 421 Kysucká & 39,80 & 51,38 & 6,21 & 8,01 & & \\
\hline TS 422 Vystavby & 39,83 & 51,42 & 16,70 & 21,56 & & \\
\hline TS 423 L’udová & 37,73 & 48,70 & 10,11 & 13,05 & & \\
\hline TS 424 Slobody & 33,32 & 43,01 & 10,01 & 12,92 & & \\
\hline TS 430 Hronská & 34,46 & 43,40 & 12,04 & 17,00 & & \\
\hline
\end{tabular}

Table 4: Comparison of assessed values (EC) with legislation for impact on the population.

\begin{tabular}{|c|c|c|c|c|c|c|}
\hline Identification of & $\begin{array}{l}\text { Measured values of } \\
\text { electric field intensity }\end{array}$ & $\begin{array}{l}\text { Eef values plus } \\
\text { expanded uncertainty }\end{array}$ & $\begin{array}{l}\text { Measured values of } \\
\text { magnetic induction }\end{array}$ & $\begin{array}{l}\text { Bef values plus } \\
\text { expanded uncertainty }\end{array}$ & $\begin{array}{l}\text { Action value for } \\
\text { electric field strength }\end{array}$ & $\begin{array}{l}\text { Action value for } \\
\text { magnetic induction }\end{array}$ \\
\hline & $E_{e f}\left[V \cdot m^{-1}\right]$ & $E_{c}\left[V \cdot m^{-1}\right]$ & $B_{\text {ef }}[\mu T]$ & $B_{c}[\mu T]$ & $E_{R}\left[V \cdot m^{-1}\right]$ & $B_{R}[\mu T]$ \\
\hline TS 403 Obrody & 0,78 & 1,02 & 0,69 & 0,89 & \multirow{10}{*}{5000} & \multirow{10}{*}{100} \\
\hline TS 409 Sokolovská & 0,72 & 0,93 & 0,68 & 0,88 & & \\
\hline TS 411 Pokroku & 0,74 & 0,96 & 0,60 & 0,77 & & \\
\hline TS 415 Obrody & 0,87 & 1,13 & 0,73 & 0,94 & & \\
\hline TS 419 Čapajevova & 1,25 & 1,61 & 0,61 & 0,79 & & \\
\hline TS 421 Kysucká & 0,85 & 1,11 & 0,65 & 0,84 & & \\
\hline TS 422 Vystavby & 0,88 & 1,15 & 0,60 & 0,77 & & \\
\hline TS 423 L’udová & 0,94 & 1,22 & 0,70 & 0,90 & & \\
\hline TS 424 Slobody & 0,78 & 1,01 & 0,68 & 0,88 & & \\
\hline TS 430 Hronská & 0,84 & 1,10 & 0,69 & 0,89 & & \\
\hline
\end{tabular}

Government of the Slovak Republic no. 329/2006 Coll. on minimum health and safety requirements for the protection of workers before the risks related to the exposure to the electromagnetic field, we can state that in all of the transformer substations assessed, the EC field strength values assessed did not exceed the ER field intensity values and the BC field strength induced values did not exceed the BR magnetic induction action values [7]. Based on the results of measurements of electric field intensity and magnetic induction evaluated for the frequency of $50 \mathrm{~Hz}$, in places where mostly residents of dwellings move and thus in front of objects of transformer stations in the external environment it can be stated, pursuant to Decree of the Ministry of Health of the Slovak Republic No. 534/2007 Coll. on details of requirements for sources of electromagnetic radiation and for occupational exposure limits to electromagnetic radiation in the environment, that in all of the transformer stations assessed, the effective values of the electric field intensity EC did not exceed the action values of the electric field intensity ER and also the assessed effective values of the magnetic induction $B C$ did not exceed the action values of the magnetic induction BR [8].

\section{Recommended measures for improving the state}

We used SchetchUp 2019 environment for creation of the transformer station model with internal elements of electric transmission and transformation systems. In this 3D program, a detailed drawing of the transformer station, which is an exact copy of the TS located in our assessed 
areas, was modelled. A 3D view of the external structure of the transformer station object is shown in Fig 5. 3D views of the interior of the building with the relevant technological elements of electrical equipment are shown in Fig. 6 and Fig. 7.
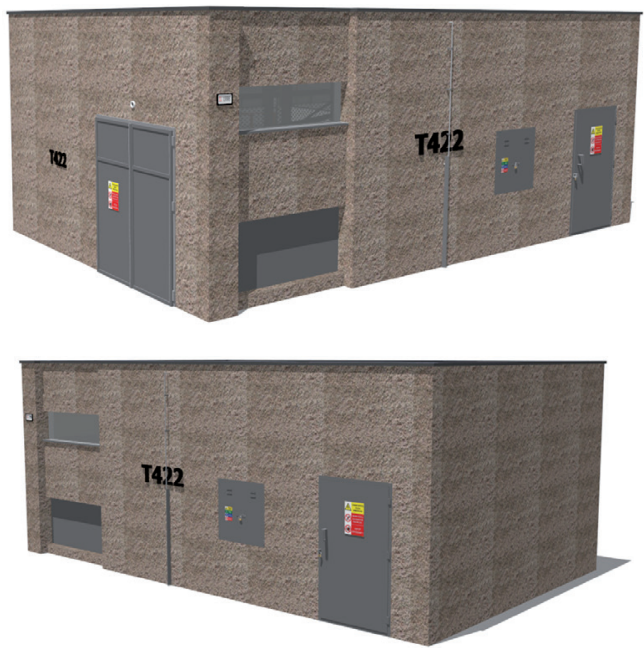

Figure 5: Visualization of transformer station using SchetchUp 2019 software.

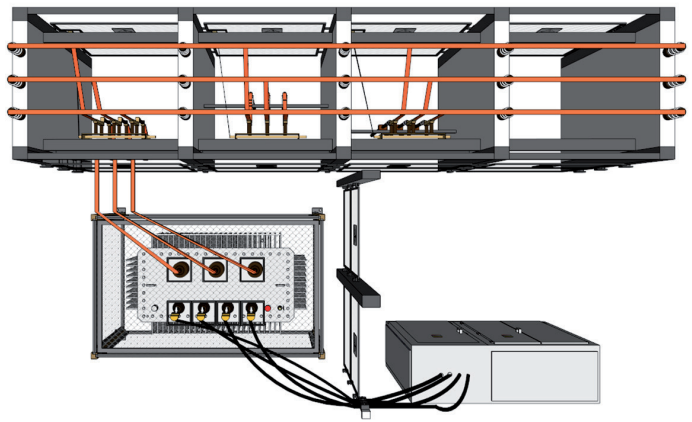

Figure 6: Visualization of the interior of the object - floor plan.

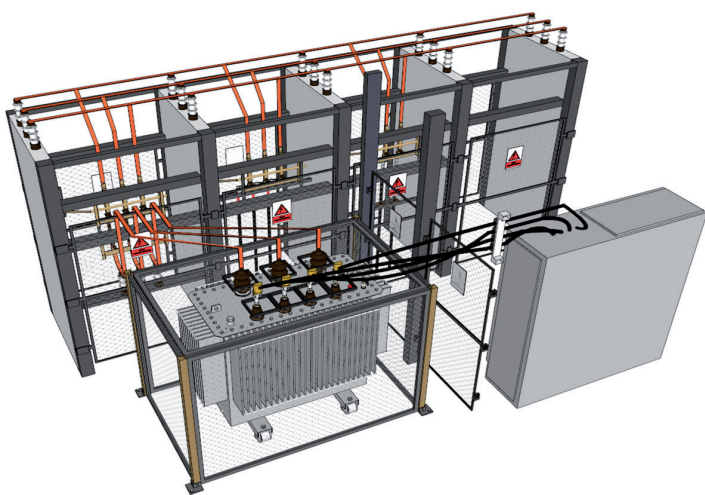

Figure 7: Side view visualization.

\section{Design solution and proposal of shielding materials}

An optimal measure that would reduce the emissions of electromagnetic fields inside the transformer station, where the employees of the East Slovakian Power Plant are located, would be possible with the Faraday Cage, which is shown in Fig. 8, Fig. 9, and Fig. 10.

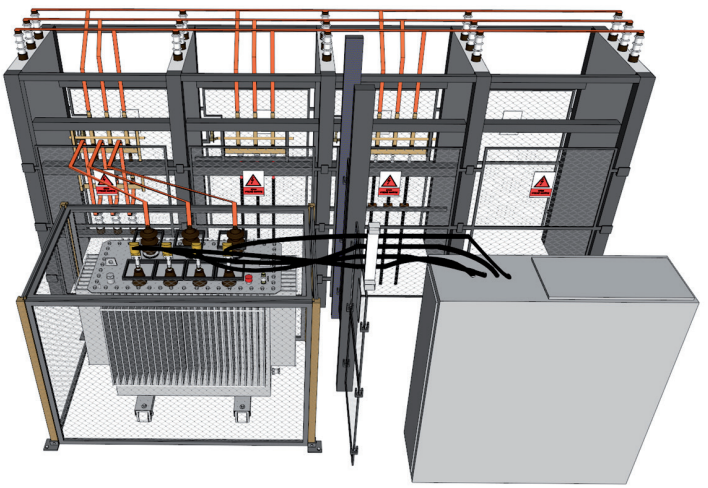

Figure 8: Visualization of Faraday cage using SchetchUp 2019.

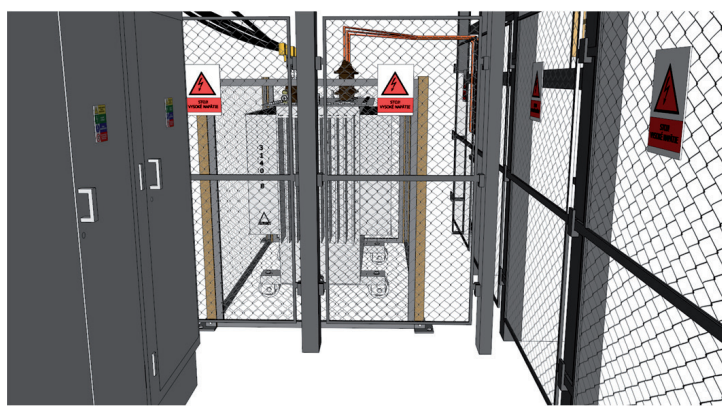

Figure 9: Visualization of Faraday cage using SchetchUp 2019.

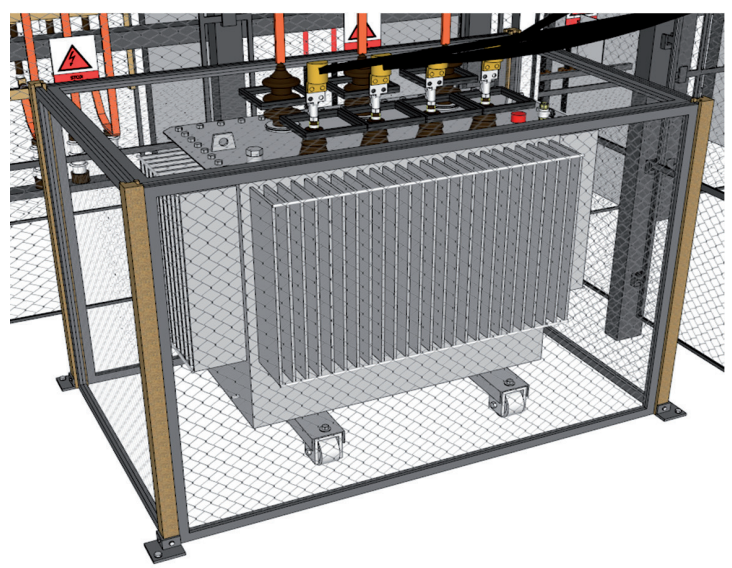

Figure 10: Visualization of Faraday cage using SchetchUp 2019. 
For this particular case, we propose a cage that would have a length $\mathrm{x}$ width $\mathrm{x}$ height of $1150 \times 1850$ $\times 1300 \mathrm{~cm}$. The dimensions of the designed Faraday cage, as well as the cage, are shown in Fig. 11.

Faraday's cage is used in practice for protection of electrical equipment. Such a cage is a completely closed cage made of electrically conductive material, for our case we suggest:

- wire mesh,

- a fabric which is interwoven with an electrically conductive (ferromagnetic) material in the form of thin fibres.

This solution has the effect of reducing the emission of electromagnetic fields into the environment as well as the opposite effect, i.e. the transformer is protected against external influences of electromagnetism as other sources or lightning.

The supporting structure of this cage is designed of wood, the surface of which will be treated by, for example:

- a coat of paint with ferrite powder mixed with synthetic dye,

- or treated with ferromagnetic foil.

The whole construction will consist of 5 parts, which will fit together by means of wooden grooves and pins (Fig. 12 and Fig 13), commonly used in the wood industry for joining parts. This design solution is designed for quick dismantling of the structure, thus ensuring quick operator access to the transformer in case of maintenance or repairs.
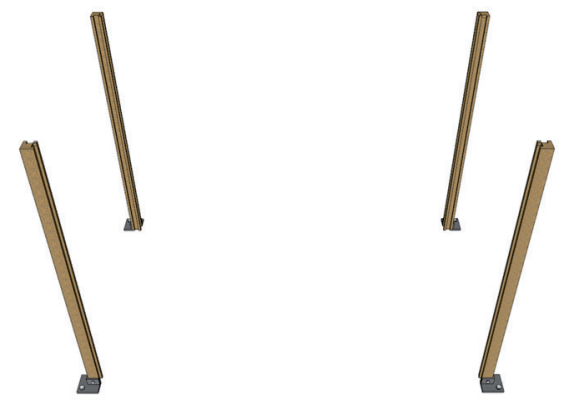

Figure 11: A view of the grooves of the wooden load-bearing structure.

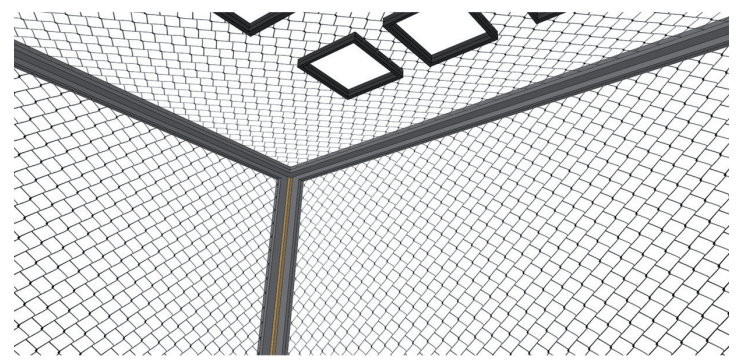

Figure 12: Detail view of side parts mounted in grooves.

\section{Conclusion}

On the basis of measurements of electromagnetic field parameters in transformer station objects, it was found that the action values described in Government Regulation no. 329/2006 Coll. and directive of the Ministry of Health of the Slovak Republic no. 534/2007 Coll. were not exceeded in any of our substations, and residents moving near these transformer stations are exposed to electromagnetic radiation only to a minimum extent. VSE staff is exposed to this electromagnetic radiation, whether short- or long-term, particularly when carrying out regular inspections of such equipment; or for repairs and maintenance. Of course, the effects of electromagnetic fields impact is manifested differently for each person, and set action values are converted to a single number.

In this case, is an action value for $50 \mathrm{~Hz}$ for an electric field intensity (E) of $10000 \mathrm{~V} / \mathrm{m}$ and for magnetic induction (B) $500 \mu \mathrm{T}$. Measured values with added expanded uncertainty are about 200 times lower than the action value for $\mathrm{E}$ and about 30 times lower than the action value for $\mathrm{B}$. The aim was to compare these measurements with action values in the relevant legislation of the Slovak Republic, and to evaluate the exposure of employees and inhabitants to electromagnetic fields. Another aim was to propose a design that would reduce the electromagnetic radiation of these sources. This measure is designed as a cubic Faraday cage made of electrically conductive material.

\section{Acknowledgments}

This contribution was created within the project KEGA 032 TUKE-4/2018 Intensification and Information Processes in Environmental Quality Engineering (50 \%) and APVV - 15-0327 Development and research of methodologies for optimization of acoustic properties and acoustic quality of noise emitting devices (50\%).

\section{References and Notes}

1. LUMNITZER, E., DRAHOŠ, R., LIPTAI, P., 2014. Elektromagnetické polia v životnom a pracovnom prostredí. TU, Košice. 96 s. ISBN 978-80-553-1910-0.

2. STN EN 50413: 2009, Základná norma na postup merania a výpočtu expozície osôb elektrickými, magnetickými a elektro-magnetickými poliami (0 Hz-300 GHz).

3. Zákon č. 142/2000 Z. z. o metrológii a o zmene a doplnení niektorých zákonov.

4. Merací retazec Narda EFA 300 so sondami. [online]. 2018 
[cit. 2019-11.16]. <https://www.nardasts.com/en/safety/ products/low-frequency/efa-300/>.

5. STN P ENV 50166-1: 2000, Vystavenie ludského organizmu pôsobeniu nízkofrekvenčných elektromagnetických polí s frekvenciou od $0 \mathrm{~Hz}$ do $10 \mathrm{kHz}$.

6. STN 332040: 1993, Ochrana pred účinkami elektromagnetického pola $50 \mathrm{~Hz}$ v pásme vplyvu zariadení elektrizačnej sústavy.

7. NV SR č. 329/ 2006 Z.z. o minimálnych zdravotných a bezpečnostných požiadavkách na ochranu zamestnancov pred rizikami súvisiacimi s expozíciou elektromagnetickému polu.

8. Vyhláška MZ SR č. 534/2007 Z.z., o podrobnostiach o požiadavkách na zdroje elektromagnetického žiarenia a na limity expozície obyvatelov elektromagnetickému žiareniu $\checkmark$ životnom prostredí.

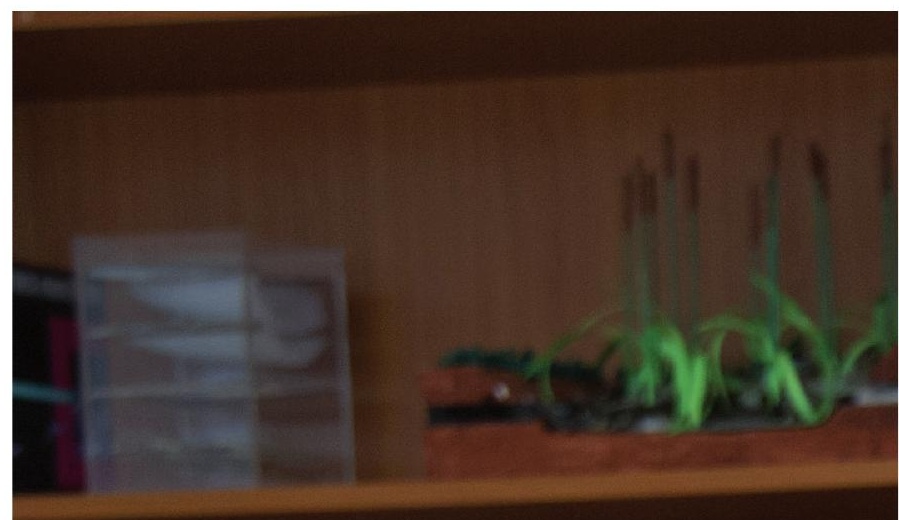

